\title{
Effect of the Integrated Use of Mineral- and Bio-Fertilizers on Yield and Some Agronomic Characteristics of Fodder Pearl Millet (Pennisetum Glaucum L.)
}

\author{
Hend E. Habiba ${ }^{1}$, Heba S.A. Salama ${ }^{2}$ and Abdelaziz T. Bondok ${ }^{1}$
}

\begin{abstract}
There is an increasing need to improve the fodder productivity of the common forage crops grown in the summer season in Egypt. Fertilizer management is among the common cultural practices that have a direct influence on the forage yield and growth attributes.

This study was carried out during two successive summer seasons (2014 and 2015) in Egypt and aimed to investigate the variations in yield and some agronomic characteristics of three successive cuts of five fodder pearl millet cultivars under integrated use of nitrobine biofertilizer with different doses of mineral nitrogen fertilizer. The studied fertilization treatments were; 60 and $90 \mathrm{~kg}$ mineral $\mathrm{N}_{\text {fed }}{ }^{-1}$ alone and the same doses accompanied with nitrobine bio-fertilizer application. In addition to fresh and dry yields (ton fed ${ }^{-1}$ ), and dry matter content $\left(\mathrm{g} \mathrm{kg}^{-1}\right)$, the following agronomic characteristics were evaluated; plant height $(\mathrm{cm})$, stem diameter $(\mathrm{mm})$, number of leaves per plant, leaf area per plant $\left(\mathrm{cm}^{2}\right)$, number of tillers $\left(\mathrm{m}^{-2}\right)$ and leaf/stem ratio. A pronounced response in almost all the studied parameters to the different fertilization treatments was achieved for the three investigated cuts for both growing seasons. The application of bio-fertilizer accompanied with 60 or $90 \mathrm{~kg} \mathrm{~N}$ produced the highest significant fresh and dry yields. No significant variation was detected among the tested fertilizer treatments for the dry matter accumulation of the $1^{\text {st }}$ cut, while the application of $60 \mathrm{~kg}$ mineral $\mathrm{N}^{-1} \mathrm{fed}^{-1}$ in addition to biofertilizer accumulated the highest amount of dry matter for the $2^{\text {nd }}$ and $3^{\text {rd }}$ cuts. Similar to the yield results, the integration of bio-fertilizer with 60 or $90 \mathrm{~kg}$ mineral $\mathrm{N}$ fed $^{-1}$ resulted in better growth attributes. Giza 1 and Giza 2 proved to be high yielding cultivars with superiority in the studied growth attributes. Meanwhile, Shandaweel 1 and Sharq El Owainat were inferior to the other cultivars. Investigating the three successive cuts revealed that the values for all the studied parameters were the highest in case of the $1^{\text {st }}$ cut and then gradually decreased till reaching the lowest values for the $3^{\text {rd }}$ cut. It is recommended to integrate nitrobine bio-fertilizer with low doses of mineral $\mathbf{N}$ fertilizer in the production of fodder pearl millet.
\end{abstract}

Keywords: Pearl millet, Forage, Bio-fertilizer, Yield, growth attributes.

\section{INTRODUCTION}

The forage production sector in Egypt suffers from marked seasonal fluctuations especially in the summer season, where the feed shortage reach its peak. Therefore, more attention should be directed towards increasing the productivity of the common summer forage crops, to overcome the deficiency of green forage during the summer season (Ibrahim et al., 2015; Salama and Zeid, 2016). Pearl millet (Pennisetum glaucum L.) is a summer annual crop grown in Egypt mainly for forage production. Compared to other summer forage grasses, like fodder maize and sorghum, pearl millet is advantaged by its high tillering potential, drought and heat tolerance (Salama and Zeid, 2016; Jukanti et al. 2016), its ability to grow in low fertility soils (Ali, 2010), its low demand for nutrients, yet ability to produce satisfactory amounts of yield (Maman et al., 2000) and dry matter (Ayub et al., 2007). The crop is widely known for its ability to provide stable grain and forage yields, even when subject to crop production constraints like poor, sandy soils, and hot and dry environments (Jukanti et al. 2016). Moreover, pearl millet is preferred by many dairy and meat producing farmers, because, compared to sorghum, it has very low values for hydrocyanic acid potential (Geweifel, 1997).

Soil infertility is the most important constraint standing for low crop productivity, especially in the developing countries. Fertilization is, therefore, amongst the most important cultural practices that need to be carefully adjusted to achieve maximum production from any forage crop. Fertilizer nitrogen $(\mathrm{N})$ application has a direct and positive effect on the herbage growth and quality (Lantinga et al., 1999; Nevens and Reheul, 2003). Therefore, mineral $\mathrm{N}$ fertilization is a key input in the Egyptian agricultural system. Nonetheless, the increased application of mineral $\mathrm{N}$ fertilization is one of the major sources for environmental pollution, caused by leaching and run off. In addition, the constantly increasing prices of the mineral fertilizers are adding another financial burden to the farmers and pushing towards finding other more affordable, yet environmentally friendly, alternatives.

\footnotetext{
${ }^{1}$ Forage Crops Research Department, Field Crops Research Institute, Agricultural Research Center (ARC), Giza, Egypt

${ }^{2}$ Crop Science Department, Faculty of Agriculture,

Alexandria University, Alexandria, Egypt

Received May 02, 2018, Accepted June 26, 2018
} 
Bio-fertilizers, or so called "microbial inoculants", are important components of integrated nutrients management. As cheap and environmentally friendly sources of plant nutrients, bio-fertilizers could be safely used for sustainable crop production, especially in low input agricultural systems (El-Kholy and Gomaa, 2000). Microbial inoculants have the ability to promote plant growth, enhance nutrient availability and uptake, and support the health of plants (Han and Lee 2005; Adesemoye et al. 2008). While acting as natural stimulators for plant growth and development, biofertilizers play a key role in productivity and sustainability of soil (Abdel Ghany et al., 2013).

Biological nitrogen fixation is an effective way of converting the nitrogen from the elemental form, unavailable for plant usage, to the plant usable form (Gothwal et al., 2007). Nitrogen fixing bio-fertilizers are composed of microbial inoculants that are able to fix atmospheric nitrogen. Among the nitrogen fixers, Azospirillum species are a group of free living bacteria, known as broad spectrum bio-fertilizers (Gupta, 2004). In addition to their role as nitrogen fixers, Azospirillum spp. are known for their stimulating effect on shoot and root development (Noshin et al., 2008), as well as increasing the rate of water and mineral uptake by roots (Gonzalez et al., 2005). As a result, a distinguished improvement in the plant's ability to grow even in presence of various stress conditions is achieved (Creus et al., 1996). Nonetheless, Azospirillum species have been widely tested to increase the yield of different cereal crops under field conditions (Simon, 2003; Mohammadi and Sohrabi, 2012). El-Komy (2005) reported the advantage of co-inoculation by Azospirillum lipoferum, in providing balanced nitrogen nutrition for wheat plants. Moreover, Fulchieri and Frioni (1994) observed that inoculation of maize with Azospirillum had enhanced the yield and dry weight of seeds.

Recently, the integration of bio-fertilizers in the Egyptian forage production system has been gaining increased attention as a useful strategy to decrease the use of chemical fertilizers and, thus, limit their harmful effects on the water and soil (Helmy, 2003). It was, however, reported by Zerbini and Thomas (2003) and Hend (2017) that the use of bio-fertilizers alone is not sufficient to reach the maximum crop productivity. They also suggested that when the bio-fertilizer partially substitutes the chemical fertilizer, better results in terms of yield are achieved, as the bio-fertilizer is supposed to increase the use efficiency of the low amount of used chemical fertilizer. It is, therefore, proposed that combining bio-fertilizers with chemical fertilizers, would improve productivity and quality of various forage crops, and at the same time, decrease the amount of used chemical fertilizer, which will reduce the costs and save the environment.

The main aim of the current study was to evaluate the productivity and some agronomic characteristics of three cuts taken from five fodder pearl millet cultivars under different mineral nitrogen fertilizer applications, integrated with nitrobine bio-fertilizer.

\section{MATERIALS AND METHODS}

\section{Experimental location:}

A field trial was conducted during two successive summer seasons (2014 and 2015) at Gemmiza experimental station, Gharbeia governorate, Egypt. Mechanical and chemical analyses of the experimental soil are presented in Tables (1) and (2), respectively.

\section{Treatments and management:}

A split plot experimental design, in three replications, was adopted to study the effect of mineral and/or bio-fertilizer applications on the yield, dry matter content, and some agronomic characteristics of four pearl millet cultivars, compared with the reference commercial cultivar, Shandaweel 1.

The tested fertilizer applications, assigned to the main plots, were; $60 \mathrm{~kg}$ mineral nitrogen $(\mathrm{N} 1), 60 \mathrm{~kg}$ mineral nitrogen + Bio-fertilizer $(\mathrm{N} 2), 90 \mathrm{~kg}$ mineral nitrogen (N3), and $90 \mathrm{~kg}$ mineral nitrogen + Biofertilizer (N4) per feddan. Mineral nitrogen was applied in the form of urea $(46 \% \mathrm{~N})$, and each nitrogen rate under study was split into three equal doses. First nitrogen dose was applied to the experimental plots 14 days after sowing, while second and third doses were applied after the first and second cuts, respectively. The applied bio-fertilizer was Nitrobine, containing Azospirillum species (free non-symbiotic nitrogen-fixing bacteria). Nitrobein inoculum was provided by the Microorganisms unit, Agricultural Research Center (ARC), Giza, Egypt. Seed inoculation was done by mixing pearl millet grains with the inoculum, and Arabic gum was used to ensure complete adhesion. The coated grains were air-dried in shade for 30 minutes then directly sown and immediately covered with soil to avoid bacterial exposure to the sun. Cross contamination of uninoculated seeds was avoided by sowing them prior to the inoculated seeds

Meanwhile, the five investigated pearl millet cultivars, namely; Shandaweel 1 (G1), Giza 1 (G2), Sids (G3), Sharq El Owainat (G4), and Giza 2 (G5), were tested in the subplots. 
Table 1. Mechanical analysis of the experimental soil

\begin{tabular}{ccccccc}
\hline Soil texture & Course Sand \% & Fine sand \% & Silt \% & Clay \% & E.C. dS m & $\mathrm{CaCO}_{3} \%$ \\
\hline Clay loam & 2.68 & 9.50 & 26.30 & 61.52 & 1.45 & 3.30 \\
\hline
\end{tabular}

Table 2. Macro- and micro-nutrients availability in the experimental soil

$\begin{array}{llll}\text { Organic matter \% } & \text { Available N ppm } & \text { Available P ppm } & \text { Available K ppm }\end{array}$

1.89225 .5

The experimental plots were sown on the $1^{\text {st }}$ of May in 2014 and 2015. The plot size was $3 * 3 \mathrm{~m}$, which contained 5 ridges $60 \mathrm{~cm}$ apart. Sowing was done in hills $20 \mathrm{~cm}$ apart, on one side of the ridge, with $20 \mathrm{~kg}$ $\mathrm{fed}^{-1}$ seeding rate. All plots were treated similarly, i.e. fertilized and harvested three times at the same interval in each growing season. Calcium superphosphate $\left(15.5 \% \mathrm{P}_{2} \mathrm{O}_{5}\right)$ and potassium sulphate $\left(48 \% \mathrm{~K}_{2} \mathrm{O}\right)$ were applied to all experimental plots with the recommended rate of 150 and $50 \mathrm{~kg} \mathrm{fed}^{-1}$, respectively, before sowing. First cut was taken at 45 days after sowing (DAS), with 35 days interval between each two successive cuts till the third cut. Broadleaf and grass weeds were handremoved from plots and no serious incidence of insects or diseases was observed.

\section{Investigated parameters:}

At the time of each cut, plots were manually cut with a sickle $7 \mathrm{~cm}$ above the ground surface and the total yield per cut per plot was weighed. A representative sub-sample of approximately $500 \mathrm{~g}$ fresh matter per plot was dried at $60{ }^{\circ} \mathrm{C}$ until constant weight to determine the dry matter (DM) content, upon which the dry yield per plot was estimated. Another sub sample of $500 \mathrm{~g}$ fresh matter per plot was separated to leaves and stems, and each component was weighed to determine the fresh leaf/stem ratio. Plant height $(\mathrm{cm})$, stem diameter $(\mathrm{cm})$, number of leaves per plant, and leaf area per plant $\left(\mathrm{cm}^{2}\right)$ were calculated as an average of 5 randomly taken plants from the middle ridges in each plot. In the middle of each plot, tillers were counted in one $\mathrm{m}^{2}$.

\section{Statistical analysis:}

The tested pearl millet cultivars, fertilizer applications as well as their interactions, for each of the three cuts, were tested for significance using Proc Mixed of SAS 9.1 (SAS Institute, Inc., 2012). Data from 2014 and 2015 growing seasons are separately presented and discussed, because the test of homogeneity of variance (Winer, 1971), when performed, revealed that the error of the variance between the two experimental seasons was heterogeneous.

Only replicates were considered random. The investigated parameters $(P)$ then were analysed according to the following model:

$P i j k=\mu+G i+F j+R k+e i j k+(G x F) i j+s i j k$

where $\mu$ is the overall mean, $\mathrm{G}_{i}$ is the cultivar effect $(i=1,2,3,4,5), \mathrm{F}_{j}$ is the fertilizer treatment effect $(j=$ $1,2,3,4), \mathrm{R}_{k}$ is the replication ( $\left.k=1,2,3\right), \mathrm{e}_{i j k}$ is the effect of main plot, $(\mathrm{G} \times \mathrm{F})_{i j}$ is the effect of the interaction between the cultivar and fertilizer treatment, and $s_{i j k}$ is the effect of sub-plot.

Significance was declared at $P<0.05$ and means were compared with the least-significant difference (L.S.D) procedure.

\section{RERSULTS}

Data of the yield and dry matter content, as well as the studied agronomic characteristics will be presented. Main effects of the studied factors will be presented and discussed when the interaction is not significant.

\section{Fertilizer-related variations:}

\section{Yield and dry matter content:}

Analysis of variance revealed that fresh and dry yields, and dry matter content were significantly variable among the four tested fertilizer applications for the three investigated cuts. Means presented in table (3) illustrate that, during both growing seasons, the significantly lowest fresh yield $\mathrm{fed}^{-1}$ was produced with 60 units $\mathrm{N}$ within each cut. In the first growing season, no significant variation was observed between the other three fertilizer treatments, while, in the second growing season, the application of bio-fertilizer accompanied with 60 or $90 \mathrm{~kg} \mathrm{~N}$ produced the significantly highest fresh yield for the three cuts. The highest amount of fresh yield produced for the three successive cuts amounted to $22.92,13.59$, and 4.80 ton $\mathrm{fed}^{-1}$, for 2014 , and $14.97,11.83$, and 9.97 ton $\mathrm{fed}^{-1}$ for 2015. The total fresh yield $\mathrm{fed}^{-1}$ of the three cuts per growing season ranged from 37.92 to 40.83 ton and from 32.78 to 36.78 ton for the first and second growing seasons, respectively. Nonetheless, the application of biofertilizer, in addition to a certain dose of mineral $\mathrm{N}$, resulted in an increase in the fresh yield compared to the application of the same dose of mineral $\mathrm{N}$ alone.

Noticeably, the amount of fresh yield $\mathrm{fed}^{-1}$, was the highest in the $1^{\text {st }}$ cut and decreased with each successive cut, during both growing seasons. Similar to the fresh yield results, it was observed that in 2014, the application of $60 \mathrm{~kg} \mathrm{~N} \mathrm{fed}^{-1}$ resulted in the significantly lowest dry yield production for the three cuts. However, no significant variation was observed among the other 
fertilizer applications. Partially similar results were reported for 2015, where, the significantly highest amount of dry yield was produced with $90 \mathrm{~kg} \mathrm{~N}$ with bio-fertilizer, followed by the other three fertilizer applications. The three cuts produced a total dry yield ranging from 6.11 to 6.64 ton $\mathrm{fed}^{-1}$, in 2014 , and from 6.16 to 7.24 ton $\mathrm{fed}^{-1}$, in 2015 . Obviously, similar to fresh yield, the amount of dry yield $\mathrm{fed}^{-1}$, was the highest in the $1^{\text {st }}$ cut and decreased with each successive cut, during both growing seasons.

Means of dry matter content, presented in table (3), show that, for the $1^{\text {st }}$ cut in both growing seasons, no significant variation was detected among the four tested fertilizer treatments. However, in 2014, the application of $60 \mathrm{~kg} \mathrm{~N}+$ bio-fertilizer was similar to the application of $90 \mathrm{~kg}$ mineral $\mathrm{N}$ alone, in accumulating the significantly highest amount of dry matter for the $2^{\text {nd }}$ and $3^{\text {rd }}$ cuts. Similar results were reported for the $2^{\text {nd }}$ and $3^{\text {rd }}$ cuts in 2015, where the application of $60 \mathrm{~kg} \mathrm{~N}+$ biofertilizer resulted in the highest dry matter content followed by the application of $90 \mathrm{~kg}$ mineral $\mathrm{N}$ alone. On the other hand, the significantly lowest dry matter accumulation was observed with the application of the lowest mineral $\mathrm{N}$ dose (60 kg alone), and unexpectedly, with the application of the highest mineral $\mathrm{N}$ dose $(90$ $\mathrm{kg}$ ) in combination with the bio-fertilizer. Moreover, the dry matter accumulation declined with the successive cuttings. The amount of decrease in dry matter accumulation was more pronounced in the $2^{\text {nd }}$ growing season and reached, 8.94, 4.76, 7.75, and $8.93 \%$ for the four respective tested fertilizer applications.

Table 3. Means of fresh and dry yield (ton fed $\left.{ }^{-1}\right)$, and dry matter content $\left(\mathrm{g} \mathrm{kg}^{-1}\right)$ for the three cuts as affected by the variation among the four tested fertilization treatments in 2014 and 2015 growing seasons

\begin{tabular}{clllllll}
\hline Parameter & $\begin{array}{l}\text { Fertilizer } \\
\text { treatment }\end{array}$ & \multicolumn{3}{c}{ Growing season 2014 } & \multicolumn{3}{c}{ Growing season 2015 } \\
\cline { 2 - 7 } & N1 & $21.67 \mathrm{~b}^{*}$ & $12.46 \mathrm{~b}$ & $3.79 \mathrm{~b}$ & $13.06 \mathrm{c}$ & $10.17 \mathrm{c}$ & $9.46 \mathrm{~b}$ \\
& $\mathrm{~N} 2$ & $22.77 \mathrm{a}$ & $13.26 \mathrm{a}$ & $4.80 \mathrm{a}$ & $14.85 \mathrm{a}$ & $11.62 \mathrm{a}$ & $9.90 \mathrm{a}$ \\
Fresh yield & $\mathrm{N} 3$ & $22.45 \mathrm{a}$ & $13.72 \mathrm{a}$ & $4.32 \mathrm{a}$ & $13.87 \mathrm{~b}$ & $11.10 \mathrm{~b}$ & $9.59 \mathrm{~b}$ \\
ton fed $^{-1}$ ) & N4 & $22.92 \mathrm{a}$ & $13.59 \mathrm{a}$ & $4.30 \mathrm{a}$ & $14.97 \mathrm{a}$ & $11.83 \mathrm{a}$ & $9.97 \mathrm{a}$ \\
& L.S.D. 0.05 & 0.85 & 0.65 & 0.57 & 0.353 & 0.27 & 0.14 \\
& N1 & $3.42 \mathrm{~b}$ & $2.09 \mathrm{~b}$ & $0.60 \mathrm{~b}$ & $2.92 \mathrm{~b}$ & $1.97 \mathrm{~d}$ & $1.27 \mathrm{c}$ \\
& $\mathrm{N} 2$ & $3.63 \mathrm{a}$ & $2.19 \mathrm{ab}$ & $0.66 \mathrm{a}$ & $3.11 \mathrm{~b}$ & $2.17 \mathrm{~b}$ & $1.47 \mathrm{~b}$ \\
Dry yield & N3 & $3.59 \mathrm{a}$ & $2.34 \mathrm{a}$ & $0.64 \mathrm{a}$ & $3.12 \mathrm{~b}$ & $2.12 \mathrm{c}$ & $1.32 \mathrm{c}$ \\
ton fed $^{-1}$ ) & N4 & $3.66 \mathrm{a}$ & $2.24 \mathrm{a}$ & $0.74 \mathrm{a}$ & $3.34 \mathrm{a}$ & $2.31 \mathrm{a}$ & $1.59 \mathrm{a}$ \\
& L.S.D. 0.05 & 0.18 & 0.15 & 0.10 & 0.21 & 0.05 & 0.05 \\
& N1 & $158.50 \mathrm{a}$ & $165.20 \mathrm{~b}$ & $163.40 \mathrm{~b}$ & $223.50 \mathrm{a}$ & $176.60 \mathrm{c}$ & $134.10 \mathrm{c}$ \\
Dry matter & N2 & $159.80 \mathrm{a}$ & $167.70 \mathrm{ab}$ & $167.60 \mathrm{ab}$ & $208.90 \mathrm{a}$ & $213.70 \mathrm{a}$ & $161.30 \mathrm{a}$ \\
$\left(\mathrm{g} \mathrm{kg}^{-1}\right)$ & N3 & $158.40 \mathrm{a}$ & $170.10 \mathrm{a}$ & $169.40 \mathrm{a}$ & $226.00 \mathrm{a}$ & $195.50 \mathrm{~b}$ & $148.50 \mathrm{~b}$ \\
& N4 & $160.10 \mathrm{a}$ & $165.00 \mathrm{~b}$ & $162.20 \mathrm{~b}$ & $222.30 \mathrm{a}$ & $191.10 \mathrm{~b}$ & $133.00 \mathrm{c}$ \\
& L.S.D.0.05 & 2.21 & 4.45 & 5.86 & 8.50 & 6.80 & 6.20 \\
\hline
\end{tabular}

* Means followed by the same small letter(s) within the same growing season and cut are not significantly different at 0.05 level of probability.

\section{Agronomic characteristics:}

Data in table (4) present the variations within the plant height, stem diameter, number of leaves per plant and leaf area per plant as affected by the four tested fertilizer applications. The application of bio-fertilizer in addition to the highest $\mathrm{N}$ dose $\left(90\right.$ unit fed $^{-1}$ ) resulted in was true for the first cut in 2014 and the three cuts in 2015, however, for the second and third cuts in 2014, the two fertilizer treatments were insignificantly different. The significantly shortest plants were observed when 60 and $90 \mathrm{~kg}$ mineral $\mathrm{N}$ fed ${ }^{-1}$ were applied without bio-fertilizer. The difference in height between the tallest and shortest plants, attributed to the application of the bio-fertilizer, reached; $18.50,19.00,10.20 \mathrm{~cm}$, in 2014 and 17.90, 25.30, $14.90 \mathrm{~cm}$, in 2015 , for the three respective cuts. Observably, the plant height decreased with the successive cutting.

Concerning the stem diameter, the significantly thickest stems were produced with the second and fourth fertilizer applications, i.e. addition of bio-fertilizer to the mineral $\mathrm{N}$ application, within almost all the cuts during both growing seasons, except for the third cut in 2014, where no significant variation among the four tested fertilizer treatments was observed. The highest stem diameter was $13.23,10.53,9.53 \mathrm{~mm}$ in 2014 and 14.73 , $11.86,10.60 \mathrm{~mm}$ in 2015 , for the $1^{\mathrm{st}}, 2^{\text {nd }}$, and $3^{\text {rd }}$ cuts, respectively. Noticeably, the thickest stems were those of the $1^{\text {st }}$ cut followed by the $2^{\text {nd }}$ cut and $3^{\text {rd }}$ cut. the production of the significantly tallest plants followed by the bio-fertilizer application plus $60 \mathrm{~kg} \mathrm{~N}^{-1}$. This 
Table 4. Means of plant height $(\mathrm{cm})$, stem diameter $(\mathrm{mm})$, number of leaves per plant, and leaf area per plant $\left(\mathrm{cm}^{2}\right)$ for the three cuts as affected by the variation among the four tested fertilization treatments in 2014 and 2015 growing seasons

\begin{tabular}{|c|c|c|c|c|c|c|c|}
\hline \multirow[t]{2}{*}{ Parameter } & \multirow{2}{*}{$\begin{array}{l}\text { Fertilizer } \\
\text { treatment }\end{array}$} & \multicolumn{3}{|c|}{ Growing season 2014} & \multicolumn{3}{|c|}{ Growing season 2015} \\
\hline & & Cut 1 & Cut 2 & Cut 3 & Cut 1 & Cut 2 & Cut 3 \\
\hline \multirow{4}{*}{$\begin{array}{l}\text { Plant height } \\
\quad(\mathrm{cm})\end{array}$} & N1 & $122.40 \mathrm{~d}^{*}$ & $103.70 \mathrm{c}$ & $98.90 \mathrm{~b}$ & $130.10 \mathrm{~d}$ & $111.80 \mathrm{c}$ & $100.00 \mathrm{c}$ \\
\hline & $\mathrm{N} 2$ & $138.30 \mathrm{~b}$ & $121.50 \mathrm{a}$ & $106.60 \mathrm{a}$ & $142.8 \mathrm{~b}$ & $127.10 \mathrm{~b}$ & $106.60 \mathrm{~b}$ \\
\hline & N3 & $125.20 \mathrm{c}$ & $106.10 \mathrm{~b}$ & $98.30 \mathrm{~b}$ & $137.50 \mathrm{c}$ & $126.90 \mathrm{~b}$ & $104.30 \mathrm{~b}$ \\
\hline & $\mathrm{N} 4$ & $140.90 \mathrm{a}$ & $122.70 \mathrm{a}$ & $108.50 \mathrm{a}$ & $148.00 \mathrm{a}$ & $137.10 \mathrm{a}$ & $114.90 \mathrm{a}$ \\
\hline \multirow{6}{*}{$\begin{array}{c}\text { Stem } \\
\text { diameter } \\
(\mathrm{mm})\end{array}$} & L.S.D.0.05 & 1.86 & 1.27 & 2.06 & 1.70 & 1.32 & 2.61 \\
\hline & N1 & $11.82 \mathrm{~b}$ & $9.26 \mathrm{c}$ & $8.66 \mathrm{a}$ & $12.40 \mathrm{c}$ & $10.26 \mathrm{~b}$ & $8.93 \mathrm{c}$ \\
\hline & $\mathrm{N} 2$ & $12.93 \mathrm{a}$ & $9.93 \mathrm{~b}$ & $9.26 \mathrm{a}$ & $14.16 \mathrm{ab}$ & $11.60 \mathrm{a}$ & $10.26 \mathrm{ab}$ \\
\hline & N3 & $11.93 \mathrm{~b}$ & $9.66 \mathrm{bc}$ & $9.13 \mathrm{a}$ & $13.60 \mathrm{~b}$ & $10.60 \mathrm{~b}$ & $9.13 \mathrm{bc}$ \\
\hline & N4 & $13.23 \mathrm{a}$ & $10.53 \mathrm{a}$ & $9.53 \mathrm{a}$ & $14.73 \mathrm{a}$ & $11.86 \mathrm{a}$ & $10.60 \mathrm{a}$ \\
\hline & L.S.D.0.05 & $0.84 \mathrm{a}$ & 0.52 & 0.91 & 0.62 & 0.42 & 1.18 \\
\hline \multirow{5}{*}{$\begin{array}{l}\text { Number of } \\
\text { leaves (plant }{ }^{-1} \text { ) }\end{array}$} & N1 & $10.20 \mathrm{a}$ & $9.26 \mathrm{~b}$ & $8.06 \mathrm{~b}$ & $11.00 \mathrm{a}$ & $10.13 \mathrm{a}$ & $8.86 \mathrm{ab}$ \\
\hline & $\mathrm{N} 2$ & $10.46 \mathrm{a}$ & $9.66 \mathrm{a}$ & $8.73 \mathrm{a}$ & $10.80 \mathrm{a}$ & $9.80 \mathrm{ab}$ & $8.26 \mathrm{c}$ \\
\hline & N3 & $10.73 \mathrm{a}$ & $9.60 \mathrm{a}$ & $8.53 \mathrm{a}$ & $10.86 \mathrm{a}$ & $9.66 \mathrm{~b}$ & $8.93 \mathrm{a}$ \\
\hline & $\mathrm{N} 4$ & $10.73 \mathrm{a}$ & $9.06 \mathrm{~b}$ & $8.66 \mathrm{a}$ & $10.73 \mathrm{a}$ & $9.26 \mathrm{c}$ & $8.46 \mathrm{bc}$ \\
\hline & L.S.D. 0.05 & 0.84 & 0.25 & 0.43 & 0.64 & 0.39 & 0.41 \\
\hline \multirow{5}{*}{$\begin{array}{l}\text { Leaf area per } \\
\text { plant }\left(\mathrm{cm}^{2}\right)\end{array}$} & N1 & $2169.60 \mathrm{~b}$ & $1759.10 \mathrm{~b}$ & $1419.30 \mathrm{~b}$ & $2444.30 \mathrm{~b}$ & $1979.80 \mathrm{~b}$ & $1506.50 \mathrm{~b}$ \\
\hline & $\mathrm{N} 2$ & $2535.80 \mathrm{a}$ & $1918.90 \mathrm{a}$ & $1579.30 \mathrm{a}$ & $2528.50 \mathrm{ab}$ & $2027.70 \mathrm{ab}$ & $1687.70 \mathrm{a}$ \\
\hline & N3 & $2619.10 \mathrm{a}$ & $1977.00 \mathrm{a}$ & $1618.60 \mathrm{a}$ & $2551.60 \mathrm{ab}$ & $2110.80 \mathrm{a}$ & $1715.70 \mathrm{a}$ \\
\hline & N4 & $2709.10 \mathrm{a}$ & $1852.00 \mathrm{a}$ & $1608.70 \mathrm{a}$ & $2704.30 \mathrm{a}$ & $2113.30 \mathrm{a}$ & $1743.20 \mathrm{a}$ \\
\hline & L.S.D.0.05 & 328.10 & 170.90 & 99.90 & 233.62 & 123.27 & 83.76 \\
\hline
\end{tabular}

*Means followed by the same small letter (s) within the same growing season and cut are not significantly different at 0.05 level of probability.

As for the number of leaves per plant, it is clear from the same table that, statistical significances were detected among the four fertilizer treatments within the $2^{\text {nd }}$ and $3^{\text {rd }}$ cuts for both seasons. However, differences were negligible, and the four treatments resulted in almost the same number of leaves per plant for the three cuts. No meaningful differences in number of leaves per plant could be detected, neither within the cuts nor between the two growing seasons.

Although, it was observed that the number of leaves slightly decreased with the successive cuttings. Average number of leaves per plant for the four fertilizer treatments in the three respective cuts were 10.53, 9.40, and 8.50 in 2014, and 10.85, 9.71, and 8.63 in 2015 .

Data of leaf area per plant, presented in table (4) within the three cuts for the two growing seasons, revealed that the significantly highest leaf area was produced with the application of bio-fertilizer in addition to 60 or $90 \mathrm{~kg}$ mineral nitrogen, which didn't differ significantly from the application of $90 \mathrm{~kg}$ mineral nitrogen fertilizer alone. The application of $60 \mathrm{~kg}$ mineral nitrogen alone produced the significantly lowest leaf area per plant. Leaf area per plant for the three respective cuts, in the first growing season, ranged from 2169.60 to 2709.10 , from 1759.10 to 1977.00 , and from
1419.30 to $1618.60 \mathrm{~cm}^{2}$. Moreover, in the second growing season, leaf area per plant ranged from 2444.30 to 2704.30 , from 1979.80 to 2113.30 , and from 1506.50 to $1743.20 \mathrm{~cm}^{2}$, for the $1^{\text {st }}, 2^{\text {nd }}$, and $3^{\text {rd }}$ cuts, respectively.

\section{Cultivar-related variations:}

\section{Yield and dry matter content:}

Means of the fresh yield fed $^{-1}$ for the five tested pearl millet cultivars (Table 5), proved that Giza 1 was significantly superior to the other cultivars with fresh yield amounting to $25.53,14.52$, and 4.60 ton $\mathrm{fed}^{-1}$ for the three respective cuts in 2014, while in 2015 the three respective cuts produced $15.64,11.23$, and 11.17 ton $\mathrm{fed}^{-1}$. On the other hand, the commercial variety Shandaweel 1 produced the significantly lowest fresh yield within the three cuts for both growing seasons. Obviously, the amount of fresh yield was the highest for the $1^{\text {st }}$ cut then decreased gradually till reaching the lowest amount for the $3^{\text {rd }}$ cut. It was also observed that the first and second cuts in 2014 produced higher amounts of yield than the same cuts in 2015. Oppositely, the $3^{\text {rd }}$ cut in 2015 produced higher yield than the $3^{\text {rd }}$ cut in 2014, and this was true for the five tested cultivars. Similar results were reported for the dry yield (ton fed ${ }^{-}$ ${ }^{1}$ ), were Shandaweel 1 was by far the cultivar with the 
Table 5. Means of fresh and dry yield (ton fed $\left.{ }^{-1}\right)$, and dry matter content $\left(\mathrm{g} \mathrm{kg}^{-1}\right)$ for the three cuts as affected by the variation among the five tested cultivars in 2014 and 2015 growing seasons

\begin{tabular}{clllllll}
\hline Parameter & Fertilizer & \multicolumn{3}{c}{ Growing season 2014 } & \multicolumn{3}{c}{ Growing season 2015 } \\
\cline { 2 - 7 } & treatment & Cut 1 & Cut 2 & Cut 3 & Cut 1 & Cut 2 & Cut 3 \\
\hline & Shandaweel 1 & $16.65 \mathrm{~d}^{*}$ & $11.22 \mathrm{~d}$ & $3.07 \mathrm{c}$ & $12.62 \mathrm{e}$ & $9.92 \mathrm{c}$ & $9.08 \mathrm{~d}$ \\
& Giza 1 & $25.53 \mathrm{a}$ & $14.52 \mathrm{a}$ & $4.60 \mathrm{a}$ & $15.64 \mathrm{a}$ & $11.23 \mathrm{~b}$ & $11.17 \mathrm{a}$ \\
Fresh yield & Sids & $22.99 \mathrm{~b}$ & $13.42 \mathrm{bc}$ & $3.94 \mathrm{~b}$ & $14.37 \mathrm{c}$ & $11.66 \mathrm{a}$ & $9.50 \mathrm{c}$ \\
(ton fed $^{-1}$ ) & Sharq El Owainat & $22.21 \mathrm{c}$ & $13.18 \mathrm{c}$ & $4.19 \mathrm{a}$ & $13.71 \mathrm{~d}$ & $11.17 \mathrm{~b}$ & $9.18 \mathrm{~d}$ \\
& Giza 2 & $23.64 \mathrm{~b}$ & $13.99 \mathrm{ab}$ & $4.08 \mathrm{~b}$ & $14.63 \mathrm{~b}$ & $11.33 \mathrm{~b}$ & $10.26 \mathrm{~b}$ \\
& L.S.D.0.05 & 0.77 & 0.68 & 0.40 & 0.23 & 0.25 & 0.18 \\
& Shandaweel 1 & $2.72 \mathrm{c}$ & $1.97 \mathrm{c}$ & $0.49 \mathrm{c}$ & $2.68 \mathrm{~d}$ & $1.86 \mathrm{~d}$ & $1.10 \mathrm{~d}$ \\
& Giza 1 & $3.83 \mathrm{a}$ & $2.38 \mathrm{a}$ & $0.77 \mathrm{a}$ & $3.63 \mathrm{a}$ & $2.33 \mathrm{a}$ & $1.56 \mathrm{a}$ \\
Dry yield & Sids & $3.79 \mathrm{a}$ & $2.21 \mathrm{ab}$ & $0.66 \mathrm{~b}$ & $3.12 \mathrm{c}$ & $2.11 \mathrm{c}$ & $1.27 \mathrm{c}$ \\
$($ ton fed & (-1) \\
& Sharq El Owainat & $3.70 \mathrm{ab}$ & $2.19 \mathrm{~b}$ & $0.78 \mathrm{a}$ & $2.73 \mathrm{~d}$ & $2.15 \mathrm{c}$ & $1.23 \mathrm{c}$ \\
& Giza 2 & $3.60 \mathrm{~b}$ & $2.31 \mathrm{ab}$ & $0.67 \mathrm{~b}$ & $3.47 \mathrm{~b}$ & $2.27 \mathrm{~b}$ & $1.41 \mathrm{~b}$ \\
& L.S.D.0.05 & 0.16 & 0.16 & 0.09 & 0.14 & 0.06 & 0.07 \\
& Shandaweel 1 & $149.80 \mathrm{c}$ & $163.40 \mathrm{~b}$ & $159.50 \mathrm{c}$ & $196.40 \mathrm{c}$ & $189.30 \mathrm{c}$ & $139.30 \mathrm{~b}$ \\
& Giza 1 & $166.20 \mathrm{a}$ & $174.90 \mathrm{a}$ & $165.80 \mathrm{ab}$ & $232.30 \mathrm{a}$ & $207.80 \mathrm{a}$ & $173.70 \mathrm{a}$ \\
Dry matter & Sids & $164.80 \mathrm{a}$ & $166.10 \mathrm{~b}$ & $166.90 \mathrm{ab}$ & $217.60 \mathrm{~b}$ & $181.40 \mathrm{~d}$ & $135.00 \mathrm{~b}$ \\
$\left(\mathrm{~g} \mathrm{~kg}^{-1}\right)$ & Sharq El Owainat & $166.20 \mathrm{a}$ & $165.80 \mathrm{~b}$ & $169.50 \mathrm{a}$ & $217.80 \mathrm{~b}$ & $192.50 \mathrm{c}$ & $135.60 \mathrm{~b}$ \\
& Giza 2 & $152.40 \mathrm{~b}$ & $164.8 \mathrm{~b}$ & $163.20 \mathrm{bc}$ & $216.90 \mathrm{~b}$ & $200.2 \mathrm{~b}$ & $137.50 \mathrm{~b}$ \\
& L.S.D.0.05 & 2.66 & 4.58 & 5.89 & 11.03 & 6.47 & 8.98 \\
\hline
\end{tabular}

*Means followed by the same small letter(s) within the same growing season and cut are not significantly different at 0.05 level of probability.

significantly lowest amount of dry yield in both growing seasons. On the other hand, Giza 1 produced the highest significant dry yield in the second growing season, while, in the first growing season little differences were detected between the tested cultivars for the highest amount of dry yield. Similar to the fresh yield, higher dry yield was produced from the $1^{\text {st }}$ and $2^{\text {nd }}$ cuts in 2014 , and the $3^{\text {rd }}$ cut in 2015 than the same cuts in the other growing season.

Dry matter content data, presented in table (5), revealed that, for all the cuts in both growing seasons, the high yielding cultivar Giza 1 was among the cultivars with the significantly highest dry matter content, accompanied by Sids and Sharq El Owainat in the $1^{\text {st }}$ and $3^{\text {rd }}$ cuts in 2014 . The dry matter content for the three respective cuts for Giza 1, reached 166.20, 174.90, $165.80 \mathrm{~g} \mathrm{~kg}^{-1}$, in 2014, and 232.30, 207.80, $173.70 \mathrm{~g} \mathrm{~kg}^{-1}$, in 2015. The difference in dry matter content between the highest and lowest cultivars in 2014 , amounted to $1.64,1.15$, and $1.00 \%$ for the $1^{\text {st }}$, $2^{\text {nd }}$, and $3^{\text {rd }}$ cuts, respectively. Greater differences in dry matter content were reported for the $2^{\text {nd }}$ growing season that reached, $3.60,2.64$, and $3.87 \%$, for the three respective cuts.

\section{Agronomic characteristics:}

Means of the plant height, stem diameter, number of leaves per plant,and leaf area per plant for the three cuts as affected by the variation among the five tested cultivars in both growing seasons are presented in Table (6). A consistent trend was observed regarding the plant height of the five tested cultivars within the three cuts for the two growing seasons. Cultivar Giza 1 was characterized by the significantly tallest stems, followed by Giza 2, Sids, Sharq El Owainat and then Shandaweel 1 which was inferior with the significantly shortest stems. In general, the difference in plant height for the three respective cuts reached 57.08, 46.25, and 42.67 $\mathrm{cm}$, in 2014, and 37.13, 40.00, and $26.25 \mathrm{~cm}$, in 2015 . Nonetheless, the plant height was reduced with the successive cuts in both growing seasons.

Similar trend was reported for the stem diameter, where, cultivar Giza 1 gave the significantly thickest stems within all cuts in the two growing seasons. On the contrary, Shandaweel 1 and Sharq El Owainat were characterized by the lowest stem diameter, and Sids and Giza 2 had almost intermediate stem diameters. The difference in stem diameter between the highest and lowest values for the three respective cuts amounted to $4.17,3.00$, and $3.83 \mathrm{~mm}$ in 2014 , and $3.75,3.17$, and $3.58 \mathrm{~mm}$ in 2015 .

Regarding the number of leaves per plant, the cultivars Giza 1, Giza 2 and Sids gave the significantly highest number of leaves within all cuts in both growing seasons, followed by Sharq El Owainat, and finally, Shandaweel 1 with the least number of leaves per plant. In general, the minimum reported number of leaves per 
Table 6. Means of plant height $(\mathrm{cm})$, stem diameter $(\mathrm{mm})$, number of leaves per plant, and leaf area per plant $\left(\mathrm{cm}^{2}\right)$ for the three cuts as affected by the variation among the five tested cultivars in 2014 and 2015 growing seasons

\begin{tabular}{|c|c|c|c|c|c|c|c|}
\hline \multirow[t]{2}{*}{ Parameter } & \multirow{2}{*}{$\begin{array}{l}\text { Fertilizer } \\
\text { treatment }\end{array}$} & \multicolumn{3}{|c|}{ Growing season 2014} & \multicolumn{3}{|c|}{ Growing season 2015} \\
\hline & & Cut 1 & Cut 2 & Cut 3 & Cut 1 & Cut 2 & Cut 3 \\
\hline \multirow{5}{*}{$\begin{array}{l}\text { Plant height } \\
\text { (cm) }\end{array}$} & Shandaweel 1 & $101.58 \mathrm{e}^{*}$ & $93.66 \mathrm{e}$ & $86.83 \mathrm{e}$ & $118.62 \mathrm{e}$ & $100.91 \mathrm{e}$ & $91.58 \mathrm{e}$ \\
\hline & Giza 1 & $158.66 \mathrm{a}$ & $139.91 \mathrm{a}$ & $129.50 \mathrm{a}$ & $155.75 \mathrm{a}$ & $140.91 \mathrm{a}$ & $117.83 \mathrm{a}$ \\
\hline & Sids & $138.50 \mathrm{c}$ & $111.33 \mathrm{c}$ & $97.75 \mathrm{c}$ & $142.41 \mathrm{c}$ & $130.08 \mathrm{c}$ & $108.58 \mathrm{c}$ \\
\hline & SharqElOwainat & $117.00 \mathrm{~d}$ & $104.58 \mathrm{~d}$ & $93.91 \mathrm{~d}$ & $132.58 \mathrm{~d}$ & $120.91 \mathrm{~d}$ & $100.83 \mathrm{~d}$ \\
\hline & Giza 2 & $142.83 \mathrm{~b}$ & $118.00 \mathrm{~b}$ & $107.41 \mathrm{~b}$ & $148.75 \mathrm{~b}$ & $136.25 \mathrm{~b}$ & $113.41 \mathrm{~b}$ \\
\hline \multirow{7}{*}{$\begin{array}{c}\text { Stem } \\
\text { diameter } \\
(\mathrm{mm})\end{array}$} & L.S.D.0.05 & 2.06 & 1.64 & 1.55 & 2.29 & 2.33 & 1.93 \\
\hline & Shandaweel 1 & $10.95 \mathrm{c}$ & $8.66 \mathrm{~d}$ & $7.75 \mathrm{~d}$ & $12.25 \mathrm{~d}$ & $9.41 \mathrm{~d}$ & $7.58 \mathrm{~d}$ \\
\hline & Giza 1 & $15.12 \mathrm{a}$ & $11.66 \mathrm{a}$ & $11.58 \mathrm{a}$ & $16.00 \mathrm{a}$ & $12.58 \mathrm{a}$ & $11.16 \mathrm{a}$ \\
\hline & Sids & $12.50 \mathrm{~b}$ & $9.50 \mathrm{c}$ & $8.41 \mathrm{c}$ & $13.41 \mathrm{c}$ & $11.00 \mathrm{~b}$ & $9.33 \mathrm{c}$ \\
\hline & Sharq El Owainat & $11.08 \mathrm{c}$ & $8.83 \mathrm{~cd}$ & $7.91 \mathrm{~cd}$ & $11.91 \mathrm{~d}$ & $10.16 \mathrm{c}$ & $8.91 \mathrm{c}$ \\
\hline & Giza 2 & $12.75 \mathrm{~b}$ & $10.58 \mathrm{~b}$ & $10.08 \mathrm{~b}$ & $14.91 \mathrm{~b}$ & $12.25 \mathrm{a}$ & $10.41 \mathrm{~b}$ \\
\hline & L.S.D.0.05 & 0.50 & 0.68 & 0.66 & 0.59 & 0.63 & 0.53 \\
\hline \multirow{6}{*}{$\begin{array}{c}\text { Number of } \\
\text { leaves } \\
\left.\text { plant }^{-1}\right)\end{array}$} & Shandaweel 1 & $8.33 \mathrm{c}$ & $7.83 \mathrm{c}$ & $7.00 \mathrm{c}$ & $8.33 \mathrm{c}$ & $8.33 \mathrm{c}$ & $7.33 \mathrm{c}$ \\
\hline & Giza 1 & $11.00 \mathrm{ab}$ & $10.16 \mathrm{a}$ & $9.66 \mathrm{a}$ & $11.50 \mathrm{ab}$ & $10.58 \mathrm{a}$ & $9.83 \mathrm{a}$ \\
\hline & Sids & $11.50 \mathrm{a}$ & $10.00 \mathrm{a}$ & $9.15 \mathrm{a}$ & $11.66 \mathrm{a}$ & $10.16 \mathrm{a}$ & $8.58 \mathrm{a}$ \\
\hline & Sharq El Owainat & $10.75 \mathrm{~b}$ & $9.33 \mathrm{~b}$ & $8.66 \mathrm{~b}$ & $11.08 \mathrm{~b}$ & $9.33 \mathrm{~b}$ & $8.75 \mathrm{~b}$ \\
\hline & Giza 2 & $11.08 \mathrm{ab}$ & $9.66 \mathrm{ab}$ & $9.41 \mathrm{a}$ & $11.66 \mathrm{a}$ & $10.16 \mathrm{a}$ & $9.66 \mathrm{a}$ \\
\hline & L.S.D.0.05 & 0.50 & 0.60 & 0.55 & 0.53 & 0.46 & 0.48 \\
\hline \multirow{6}{*}{$\begin{array}{l}\text { Leaf area } \\
\text { per plant } \\
\left(\mathrm{cm}^{2}\right)\end{array}$} & Shandaweel 1 & $1730.33 \mathrm{c}$ & $1418.00 \mathrm{~d}$ & $1161.50 \mathrm{~d}$ & $1701.90 \mathrm{e}$ & $1549.12 \mathrm{~d}$ & $1251.14 \mathrm{~d}$ \\
\hline & Giza 1 & $3092.58 \mathrm{a}$ & $2429.00 \mathrm{a}$ & $1948.58 \mathrm{a}$ & $3132.54 \mathrm{a}$ & $2620.84 \mathrm{a}$ & $2070.91 \mathrm{a}$ \\
\hline & Sids & $2491.58 \mathrm{~b}$ & $1920.91 \mathrm{~b}$ & $1575.00 \mathrm{bc}$ & $2689.23 \mathrm{c}$ & $2073.66 \mathrm{~b}$ & $1682.14 \mathrm{bc}$ \\
\hline & Sharq El Owainat & $2278.91 \mathrm{~b}$ & $1746.91 \mathrm{c}$ & $1498.50 \mathrm{c}$ & $2382.86 \mathrm{~d}$ & $1864.14 \mathrm{c}$ & $1586.45 \mathrm{c}$ \\
\hline & Giza 2 & $3073.58 \mathrm{a}$ & $1994.41 \mathrm{~b}$ & $1599.33 \mathrm{~b}$ & $2879.36 \mathrm{~b}$ & $2181.71 \mathrm{~b}$ & $1725.66 \mathrm{~b}$ \\
\hline & L.S.D.0.05 & 235.04 & 158.47 & 96.92 & 161.77 & 132.47 & 97.52 \\
\hline
\end{tabular}

*Means followed by the same small letter(s) within the same growing season and cut are not significantly different at 0.05 level of probability.

plant was around 7 leaves, and the maximum was around 12 leaves.

As for the leaf area per plant, data in the same table revealed that, Giza 1 had the significantly highest leaf area values followed by Giza 2 and Sids, while Shandaweel 1 was characterized by the lowest significant leaf area per plant. Noticeably, leaf area values, especially for the $1^{\text {st }}$ cut in the two seasons, were relatively high.

This could be attributed to cutting the plants at 45 DAS, which gave them the chance to produce broader leaves.

\section{Cultivar x Fertilizer interaction:}

Analysis of variance revealed that number of tillers $\mathrm{m}^{-2}$ and fresh leaf/stem ratio were significantly affected by the two-way interaction between cultivars and fertilizer treatments for the three cuts in the two growing seasons.

Means of number of tillers $\mathrm{m}^{-2}$, presented in table (7), were highly variable as affected by the interaction. Results indicated that the significantly highest number of tillers was achieved with applying $60 \mathrm{~kg}$ mineral $\mathrm{N}+$ bio-fertilizer for all the tested cultivars, this effect was equivalent to that achieved from applying $90 \mathrm{~kg}$ mineral $\mathrm{N}$ alone. Noticeably, the application of $90 \mathrm{~kg}$ mineral $\mathrm{N}$ in addition to bio-fertilizer caused a drastic decrease in number of tillers $\mathrm{m}^{-2}$, for the five tested cultivars in almost all the cuts, despite that the same fertilizer treatment resulted in the tallest significant plants, as explained previously.

Although the direction of the effect was consistent for number of tillers $\mathrm{m}^{-2}$ of all the tested cultivars, remarkable shifts in the magnitude of the variation were observed, which contributed to the significant interaction. For example, the percentage decrease in the number of tillers $\mathrm{m}^{-2}$ produced by the low yielding cultivar Sharq El Owainat, for the three respective cuts, amounted to $28.86,18.93,14.03 \%$, in 2014, and 28.65, $16.86,14.50 \%$, in 2015 . On the other hand, the decrease in case of the high yielding cultivar, Giza 1, was more pronounced and reached, for the three respective cuts, $44.11,40.64,36.55 \%$, in 2014 , and $42.64,40.41,33.08 \%$ in 2015 . Among the tested 
Table 7. Means of number of tillers $\left(\mathrm{m}^{-2}\right)$, for the three cuts as affected by the interaction between the tested cultivars and fertilizer treatments in 2014 and 2015 growing seasons

\begin{tabular}{|c|c|c|c|c|c|c|c|c|c|c|c|c|}
\hline \multirow{4}{*}{ Cultivar } & \multicolumn{4}{|c|}{ Cut 1} & \multicolumn{4}{|c|}{ Cut 2} & \multicolumn{4}{|c|}{ Cut 3} \\
\hline & \multicolumn{4}{|c|}{ Fertilizer treatment } & \multicolumn{4}{|c|}{ Fertilizer treatment } & \multicolumn{4}{|c|}{ Fertilizer treatment } \\
\hline & N1 & $\mathbf{N} 2$ & N3 & N4 & N1 & $\mathrm{N} 2$ & N3 & N4 & N1 & $\mathbf{N 2}$ & N3 & N4 \\
\hline & \multicolumn{12}{|c|}{ Growing season 2014} \\
\hline Shandaweel 1 & 134.30 & 141.60 & 140.45 & 138.80 & 96.80 & 126.40 & 121.00 & 120.70 & 66.80 & 76.40 & 72.60 & 69.90 \\
\hline Giza 1 & 137.50 & 151.20 & 142.30 & 84.50 & 116.30 & 141.00 & 129.90 & 83.70 & 71.80 & 78.80 & 73.50 & 50.00 \\
\hline Sids & 131.50 & 157.50 & 143.40 & 106.30 & 102.10 & 146.60 & 132.30 & 103.10 & 66.10 & 78.50 & 73.50 & 58.20 \\
\hline Sharq El Owainat & 124.70 & 152.80 & 144.80 & 108.70 & 110.60 & 124.70 & 121.40 & 101.10 & 67.10 & 73.40 & 72.50 & 63.10 \\
\hline Giza 2 & 126.80 & 141.10 & 145.40 & 97.90 & 102.20 & 145.60 & 141.90 & 104.00 & 65.60 & 79.80 & 69.40 & 61.30 \\
\hline \multirow[t]{2}{*}{ L.S.D.0.05 } & \multirow{2}{*}{\multicolumn{4}{|c|}{14.64}} & \multicolumn{4}{|c|}{11.76} & \multirow{2}{*}{\multicolumn{4}{|c|}{7.44}} \\
\hline & & & & & \multicolumn{4}{|c|}{ Growing season 2015} & & & & \\
\hline Shandaweel 1 & 134.00 & 140.90 & 138.00 & 140.80 & 97.90 & 127.40 & 122.00 & 121.80 & 66.90 & 77.80 & 71.10 & 70.30 \\
\hline Giza 1 & 136.30 & 150.80 & 142.30 & 86.50 & 116.90 & 142.30 & 136.90 & 84.80 & 73.90 & 79.20 & 72.10 & 53.00 \\
\hline Sids & 129.20 & 157.20 & 143.40 & 106.20 & 101.80 & 148.20 & 131.80 & 104.50 & 67.30 & 78.00 & 74.60 & 56.20 \\
\hline Sharq El Owainat & 123.70 & 152.20 & 142.20 & 108.60 & 113.90 & 123.40 & 122.90 & 102.60 & 67.40 & 73.80 & 73.90 & 63.10 \\
\hline Giza 2 & 126.20 & 140.30 & 143.40 & 134.00 & 106.10 & 141.40 & 136.80 & 97.90 & 65.90 & 80.20 & 70.50 & 66.90 \\
\hline L.S.D. 0.05 & \multicolumn{4}{|c|}{14.34} & \multicolumn{4}{|c|}{11.82} & \multicolumn{4}{|c|}{5.14} \\
\hline
\end{tabular}

Table 8. Means of fresh leaf/stem ratio, for the three cuts as affected by the interaction between the tested cultivars and fertilizer treatments in 2014 and 2015 growing seasons

\begin{tabular}{|c|c|c|c|c|c|c|c|c|c|c|c|c|}
\hline \multirow{4}{*}{ Cultivar } & \multicolumn{4}{|c|}{ Cut 1} & \multicolumn{4}{|c|}{ Cut 2} & \multicolumn{4}{|c|}{ Cut 3} \\
\hline & \multicolumn{4}{|c|}{ Fertilizer treatment } & \multicolumn{4}{|c|}{ Fertilizer treatment } & \multicolumn{4}{|c|}{ Fertilizer treatment } \\
\hline & N1 & N2 & N3 & N4 & N1 & N2 & N3 & N4 & N1 & N2 & N3 & N4 \\
\hline & \multicolumn{12}{|c|}{ Growing season 2014} \\
\hline Shandaweel 1 & 24.93 & 31.03 & 28.03 & 25.27 & 19.97 & 25.07 & 23.87 & 22.30 & 13.20 & 15.17 & 13.70 & 13.23 \\
\hline Giza 1 & 34.80 & 27.97 & 28.00 & 35.43 & 27.27 & 23.90 & 23.53 & 27.60 & 17.40 & 13.67 & 14.10 & 17.40 \\
\hline Sids & 29.23 & 28.70 & 28.60 & 31.20 & 24.10 & 24.00 & 24.03 & 23.20 & 14.10 & 14.10 & 14.53 & 17.20 \\
\hline Sharq El Owainat & 27.17 & 26.60 & 34.03 & 27.33 & 23.70 & 22.97 & 26.07 & 22.90 & 13.30 & 13.57 & 17.33 & 13.10 \\
\hline Giza 2 & 29.43 & 32.00 & 29.83 & 32.20 & 24.13 & 25.80 & 23.17 & 25.00 & 14.47 & 16.00 & 15.87 & 14.93 \\
\hline \multirow[t]{2}{*}{ L.S.D. 0.05} & \multicolumn{4}{|c|}{0.54} & \multicolumn{4}{|c|}{1.02} & \multicolumn{4}{|c|}{0.37} \\
\hline & \multicolumn{12}{|c|}{ Growing season 2015} \\
\hline Shandaweel 1 & 25.50 & 31.23 & 29.63 & 26.27 & 17.60 & 23.00 & 21.57 & 19.07 & 14.27 & 22.40 & 19.93 & 15.53 \\
\hline Giza 1 & 34.77 & 29.43 & 29.53 & 35.93 & 28.03 & 20.33 & 23.77 & 30.97 & 27.10 & 17.83 & 21.37 & 28.07 \\
\hline Sids & 29.57 & 30.17 & 29.60 & 31.87 & 20.80 & 23.60 & 22.87 & 22.53 & 20.00 & 21.87 & 19.83 & 20.50 \\
\hline Sharq El Owainat & 29.10 & 27.80 & 34.23 & 29.97 & 19.87 & 21.27 & 28.20 & 21.03 & 16.97 & 18.73 & 25.60 & 18.67 \\
\hline Giza 2 & 30.77 & 32.67 & 31.37 & 33.63 & 25.80 & 27.20 & 22.13 & 28.27 & 24.67 & 24.00 & 19.70 & 25.10 \\
\hline L.S.D.0.05 & \multicolumn{4}{|c|}{0.88} & \multicolumn{4}{|c|}{0.79} & \multicolumn{4}{|c|}{1.20} \\
\hline
\end{tabular}


cultivars, Shandaweel 1 and Sharq El Owainat produced the lowest number of tillers $\mathrm{m}^{-2}$.

When searching for the set of treatments to achieve a compromise on the best number of tillers $\mathrm{m}^{-2}$, it appeared that growing Giza 1, Giza 2 and Sids and applying $60 \mathrm{~kg}$ mineral $\mathrm{N}+$ bio-fertilizer would be the best choice. Obviously, the highest significant number of tillers among all treatments, within each growing season, was produced from the $1^{\text {st }}$ cut followed by the $2^{\text {nd }}$ cut, while the $3^{\text {rd }}$ cut produced the lowest number of tillers $\mathrm{m}^{-2}$.

Data of leaf/stem ratio, presented in table (8), showed high variability among the tested cultivars and fertilizer treatments. The tested cultivars responded differently to the four fertilizer treatments within all cuts in the two growing seasons. The inconsistent direction of response as well as the highly variable magnitude of response might have greatly contributed to the significant two-way interaction. In general, the leaf/stem ratio significantly declined with successive cuts, where the $1^{\text {st }}$ cut was characterized with higher amounts of leaves, while the $2^{\text {nd }}$ and $3^{\text {rd }}$ cuts gave lesser amounts of leaves. This was true for all cultivars within both growing seasons.

\section{DISCUSSION}

It was clear in the current study that compensating part of the mineral $\mathrm{N}$ fertilizer with bio-fertilizer containing free nitrogen fixing bacteria, gave better yield results than the application of higher doses of mineral $\mathrm{N}$ fertilizer alone. Similar positive effects of bio-fertilizers on yield and growth of pearl millet as well as various field crops, compared to mineral fertilizers, has been well documented (e.g. Galbiatti et al., 2011; Bana et al., 2012; Abdullahi et al., 2014; Patel et al., 2014) . In her investigation to the effect of mineral, organic, and bio-fertilizers on yield and agronomic characteristics of pearl millet Shandaweel 1 cultivar, Hend (2017) reported that the application of nitrobine bio-fertilizer in combination with $60 \mathrm{~kg} \mathrm{~N}^{-\mathrm{Ned}^{-1}}$ gave similar results to the application of $120 \mathrm{~kg} \mathrm{~N} \mathrm{fed}^{-1}$ alone, for the yield and the studied agronomic characteristics. This observation is in line with the findings of the current study. She also documented that the application of nitrobine alone was not sufficient to reach the maximum productivity from the crop. Even in combination with compost, bio-fertilizers had positive effect on yield and growth of different crops as reported by Awad and Khaled (2012), who demonstrated positive effects on the growth of wheat plants fertilized with biofortified compost compared with compost alone. They attributed this to the $\mathrm{N}_{2}$-fixation ability, phosphate solubilizing capacity, indole acetic acid (IAA) and antimicrobial substance production, which are characteristics of the high effective growth promoting bacteria (Turan et al., 2005). In addition, it is evident that the interaction between the plant and the bacterial inoculant is a reason behind the enhanced $\mathrm{N}$ uptake in the plants through increasing the root surface area and the general root architecture (Vassey and Buss 2002; Lucy et al., 2004). This may explain the same amount nitrogen per gram of wheat shoot and root tissues when fertilized with $100 \%$ mineral fertilizer alone and $60 \%$ mineral fertilizer supplemented with bio-fortified compost as reported by Awad and Khaled (2012). In their investigation to the fresh and dry yields of fodder sorghum, Abo-Zeid et al. (2017), reported an increase in the yields till up to $75 \mathrm{~kg} \mathrm{~N} \mathrm{fed}^{-1}$. They attributed this increase to the role of nitrogen in enhancing the meristematic activity and cell division, which will in turn improve leaf initiation, chlorophyll composition that will encourage photosynthesis process and, thus, result in a better vegetative growth. Moreover, Wani (1990) investigated some crops inoculated with Azotobacter and Azospirillum, and reported an increase in the yields of pearl millet and sorghum due to inoculation that amounted to $11-12 \%$. An even greater yield increase, reaching $15-20 \%$, was observed in case of maize, wheat and rice.

Similar to the fresh yield, Shahin et al. (2013) reported an increase in the dry yield of three successive cuts of pearl millet with increasing nitrogen fertilization up to $75 \mathrm{~kg} \mathrm{~N} \mathrm{fed}^{-1}$. They attributed this result to the increase in photosynthetic products driven by the better leaf area, leaf weight and stem length resulting from the high $\mathrm{N}$ fertilization rates. Bana et al. (2012) suggested that yield of any species is the cumulative function of the yield components and agronomic characteristics; any treatment that positively affects these parameters, ultimately affects the biological and economical yield of the crop. Another explanation to the positive effect of bio-fertilizers on plant growth was provided by Awad and Khaled (2012), who stated that when the plants grow better under the effect of bio-fertilizers, they release higher amounts of carbon with root exudates, which in turn enhance the microbial activity and this process continues in a cycle. The whole process makes more nitrogen available from the soil pool, influencing $\mathrm{N}$ flux into plant roots. An increase in yield attributes and agronomic characteristics of pearl millet with biofertilizer application was also an important outcome of the current study, which may be due to the fact that the integrated nutrient management plays a vital role in making more nutrients available for the plant (Divya et al. 2017), leading to improved root growth and increased nutrient uptake (Singh et al. 2016). Similar results were reported by Lakum et al., (2011), Bana et al., (2012), and Patel et al., (2016). The increased 
nitrogen availability, accompanied with the application of the nitrogen fixing bio-fertilizer, will push the growth of pearl millet and the increments in internode length and/or number of internodes, resulting in significantly taller plants (Shahin et al., 2013). Similar trend was reported by Ayub et al. (2009), El-Sarag and Abu Hashem (2009) and Pathan et al. (2010). Moreover, Awad and Khaled (2012) reported that the addition of bio-fertilizers to mineral fertilizers and compost produced significantly taller plants than those fertilized only by mineral or organic fertilizers. Furthermore, Lakum et al. (2011) and Bana et al. (2012) added that the increase in plant height and agronomic characteristics with bio-fertilizer application might be due to the production of various growth regulating substances such as indoles, gibberellins and cytokinins, which contributes toward vigorous growth of plant. Similar results were reported by Patel et al. (2014), who suggested that inoculation of pearl millet seeds with the Azotobactor nitrogen fixing bacteria significantly improved the plant response due to altering the microbial balance in the rhizosphere and producing metabolites that stimulate plant development. The increase in available nitrogen also increases the number of leaves as a result of the enhanced vegetative growth (Adam, 2004).

As clarified by Singh et al. (2016), the effect of biofertilizers on the plant's growth attributes is more pronounced in the late developmental stages. In the early stages of plant development microorganisms are still in the multiplication and establishment phase, thus, the rate of nutrients mineralization is slow. However, at later developmental stages, an increased activity of microorganisms is clear in improving the nutrients' availability. Thus, an improvement of yield and growth attributes could be detected. Unlike the other growth attributes, number of tillers in the current study was the highest with the application of $60 \mathrm{~kg} \mathrm{~N}^{-1} \mathrm{~d}^{-1}$ in addition to bio-fertilizer. Similar results were reported by Shahin et al. (2013), who concluded that number of tillers increases with up to $60 \mathrm{~kg} \mathrm{~N} \mathrm{fed}{ }^{-1}$, then started decreasing with increasing the applied $\mathrm{N}$ level. An attempt to explain this result was made by Ibrahim et al. (2014), who reported a linear increase in the response of pearl millet cultivars to increased nitrogen doses till reaching a certain dose, above which the cultivars failed to utilize the additional amount of nitrogen and a decline in certain growth attributes might be observed. Furthermore, a negative relation was detected, in the current study, between number of tillers and plant height, the taller the plants, the less the number of produced tillers. This observation was consistent with the findings of Obeng et al. (2012).
An increase in the dry matter accumulation was observed in the current study when bio-fertilizer accompanied the mineral $\mathrm{N}$ application. This could be attributed to the increase in nutrients availability accompanied by the application of bio-fertilizers, especially nitrogen and phosphorus that accelerates the photosynthetic rate and thus leads to more production of carbohydrate, resulting in more dry matter accumulation (Thumar et al., 2016).

Concerning the detected significant variations among the five tested cultivars, high consistency in the results of yield and growth attributes was detected. The high yielding cultivars Giza 1 and Giza 2 were characterized by the tallest, thickest plants, highest number of leaves and leaf area per plant. The superiority in these agronomic characteristics contributed to the high productivity of the cultivars. Similar results were reported by Divya et al. (2017).

Additionally, it was observed in the current study that the values for all the studied parameters were the highest in case of the $1^{\text {st }}$ cut and then gradually decreased till reaching the lowest values for the $3^{\text {rd }}$ cut. This could be partially attributed to the age of the sward at each cutting, where the $1^{\text {st }}$ cut was taken at 45 DAS, while the $2^{\text {nd }}$ and $3^{\text {rd }}$ cuts were taken after 35 days interval. Thus, at the first cut the plants had spent longer period of time before cutting, consequently, had the chance to accumulate higher fresh fodder mass and growth characteristics. This result was in agreement with the findings of Hend (2017).

\section{CONCLUSION}

The use of bio-fertilizers to supplement mineral fertilizers is necessary for all the above mentioned advantages. Hence, the proper application of mineraland bio-fertilization is much dependent on realizing and adjusting the interactions between soil, plant and microorganisms. Microorganisms constituting biofertilizers are very useful to the plant. They have the ability to enhance plant growth through increasing nutrient availability and uptake, with minimal contribution to the environmental pollution, unlike the use of pure mineral fertilizers.

In general, Giza 1 and Giza 2 proved to be high yielding cultivars with superiority in the studied growth attributes. The integration of nitrobine bio-fertilizer with $60 \mathrm{~kg}$ mineral $\mathrm{N} \mathrm{fed}^{-1}$, resulted in better yield and agronomic characteristics than the application of the same dose of mineral $\mathrm{N}$ fertilizer alone for the three cuts of the studied cultivars. Expectedly, investigating three successive cuts revealed that the values for all the studied parameters were the highest in case of the $1^{\text {st }}$ cut and then gradually decreased till reaching the lowest values for the $3^{\text {rd }}$ cut. It is, thus, concluded that in the 
presence of nitrobine bio-fertilizer, less amounts of mineral $\mathrm{N}$ fertilizer, yet with very high use efficiency, are required to reach satisfactory yield and growth of fodder pearl millet. The integration of nitrobine biofertilizer accompanied with the use of low doses of mineral $\mathrm{N}$ fertilizer in the production of fodder pearl millet is, thus, highly recommended.

\section{REFERENCES}

Abdel Ghany, T.M., M.M. Alawlaqi and M.A. Al Abboud. 2013. Role of biofertilizers in agriculture: a brief review. Mycopath. 11:95-101.

Abdullahi, R., H.H. Sheriff and A. Buba.2014. Effect of biofertilizer and organic manure on growth and nutrients content of pearl millet. ARPN J. Agric. Biolog. Sci. 9:351-355.

Abo-Zeid, S.T., A.L. Abd El-Latif and S. Elshafey. 2017. Effects of sources and rates of nitrogen fertilizers on forage yield and nitrate accumulation for Sudangrass. Egyptian Journal of Soil Science. 57:23-30.

Adam, M.Y. 2004. Effect of seed rate and nitrogen on growth and yield of teff grass. M.Sc. Thesis.

Adesemoye, A.O., H.A. Torbert and J.W. Kloepper 2008. Enhanced plant nutrient use efficiency with PGPR and AMF in an integrated nutrient management system. Can. J. Microbiol. 54:876-886.

Ali, E.A. 2010. Grain yield and nitrogen use efficiency of pearl millet as affected by plant density, nitrogen rate and splitting in sandy soil. American-Eurasian J. Agric. Environ. Sci. 7:327-335.

Ayub, M., M. Athar Nadeem, M. Tahir, M. Ibrahim and M.N. Aslam. 2009. Effect of nitrogen application and harvesting intervals on forage yield and quality of pearl millet (Pennisetum americanum L). Pak. J. Life Soc. Sci. 7:185189.

Ayub, M., M.A. Nadeem, A. Tanveer, M. Tahir and R.M.A. Khan 2007. Interactive effect of different nitrogen levels and seeding rates on fodder yield and quality of pearl millet. Pak. J. Agric. Res. 44:592-596.

Awad, N.M., and S.M. Khaled. 2012. Maximizing effect of mineral fertilizers by compost and biofortified. Aust. J. Basic Appl. Sci. 6:482-493.

Bana, R.S., R.C. Gautam and K.S. Rana. 2012. Effect of different organic sources on productivity and quality of pearl millet (Pennisetum glaucum) and their residual effect on wheat (Triticum aestivum). Annals Agric. Res. New Series. 33:126-130.

Creus, C.M., R.J. Sueldo and C.A. Barassi. 1996. Azospirillum inoculation in pregerminating wheat seeds. Can. J. Microbiol. 42: 83-86.

Divya, G., K.P. Vani, P. Surendra Babu and K.B. Suneetha Devi 2017. Yield attributes and yield of summer pearl millet as influenced by cultivars and integrated nutrient management. Int. J. Curr. Microbiol. App. Sci. 6:14911495 .
El-Kholy, M.A. and A.M. Gomaa. 2000. Bio-fertilizers and their impact on forage yield and $\mathrm{N}$ content of millet under low level of mineral fertilizers. Annals Agric. Sci., Moshtohor. 38:813-822.

El-Komy, H.M.A. 2005. Co-immobilization of A. lipoferum and B. megaterium for plant nutrition. Food Technol. Biotechnol. 43:19-27.

El-Sarag, E.I. and G.M. Abu Hashem. 2009. Effect of irrigation intervals and nitrogen rates on forage sorghum under north Sinai conditions. Zagazig J. Agric. Res. 36:19-39.

Fulchieri, M. and L. Frioni. 1994. Azospirillum inoculation on maize (Zea mays): Effect of yield in a field experiment in Central Argentina. Soil Biol. Biochem. 26:921-924.

Galbiatti, J.A., F.G. Silva, C.F. Franco and A.D. Caramelo 2011. Desenvolvimento do fejoeiro sob o uso de biofertilizante e a dubação mineral. Engenharia Agricola. $31: 167$.

Geweifel, H.G.M. 1997. Yield and Quality of some summer forage grasses under different nitrogen levels in newly cultivated lands. Egyptian J. Appl. Sci..12:54-72.

Gothwal, R.K., V.K. Nigam, M.K. Mohan, D. Sasmal and P. Ghosh. 2007. Screening of nitrogen fixers from rhizospheric bacterial isolates associated with important desert plants. Appl. Ecol. Environ. Res. 6:101-109.

Gonzalez, L.J., B. Rodelas, C. Pozo, V. Salmeron, M.V. Martnez and V. Salmeron. 2005. Liberation of amino acids by heterotrophic nitrogen fixing bacteria. Amino Acids. 28:363-367.

Gupta, A.K. 2004. The complete technology book on biofertilizers and organic farming. National Institute of Industrial Research Press. India.

Han, H.S. and K.D. Lee 2005. Phosphate and potassium solubilizing bacteria effect on mineral uptake, soil availability, and growth of eggplant. Res. J. Agric. Biol. Sci. 1:176-180.

Helmy, A.A. 2003. Effect of N2-fixing and phosphate dissolving bacteria on yield and chemical composition of forage pearl millet (Pennisetum glaucum). J. Agric. Sci. Mansoura University. 28:5873-5885.

Hend, H.M.H. 2017. Impact of mineral, organic and biofertilization on growth, yield and quality of fodder pearl millet. American-Eurasian J. Agric. Environ. Sci., 17:450457.

Ibrahim, Y.M., A.E. Idris and M.A. Marhoum 2014. Effect of nitrogen fertilizer on irrigated forage pearl millet (Pennisetum americanum L.K. Shcum). Univ. J. Agric. Res. 2:56-60.

Ibrahim, H.I.M., E.A. Hassan and S.M.H.A. Eissa. 2015. Impact of bio-fertilization on productivity, grain quality and economic revenue of Rayana. World J. Agric. Sci. 11: 268-278.

Jukanti, A.K., C.L. Laxmipathi Gowda, K.N. Rai, V.K. Manga and R.K. Bhatt. 2016. Crops that feed the world 11. Pearl millet (Pennisetum glaucum L.): an important source of 
food security, nutrition and health in the arid and semiarid tropics. Food Security. 8:307-329.

Lakum, Y.C., S.H. Patel and P.V. Mehta. 2011. Reducing fertilizer requirement with the use of bio-fertilizers in summer pearl millet [Pennisetum glaucum (L.)]. An Asian J. Soil Sci. 6:50-53.

Lantinga, E.A., P.J.A.G. Deenen and H. Van Keulen. 1999. Herbage and animal production responses to fertilizer nitrogen in perennial ryegrass swards. II. Rotational grazing and cutting. Nether. J. Agric. Sci. 47:243-261.

Lucy, M., E. Reed and B.R. Glick 2004. Application of free living plant growth-promoting rhizobacteria. Antonie van Leeuwenhoek. 86: 1-25.

Maman, N., S.C. Mason and S. Sirifi. 2000. Influence of variety and management level on pearl millet production in Niger. Grain yield and dry matter accumulation. African Crop Sci. J. 8:25-34.

Mohammadi, K. and Y. Sohrabi. 2012. Bacterial biofertilizers for sustainable crop production: A review. ARPN J. Agric. Biolog. Sci. 7:307-316.

Nevens, F. and D. Reheul. 2003. Effects of cutting or grazing grass swards on herbage yield, nitrogen uptake and residual soil nitrate at different levels of $\mathrm{N}$ fertilization. Grass Forage Sci. 58:431-449.

Noshin, I., B. Asghari and I. Sumera. 2008. Variation in Rhizobium and Azospirillum strains isolated from maize growing in arid and semiarid areas. Int. J. Agric. Biol. 10:612-618.

Obeng, E., E. Cebert, B.P. Singh, R. Ward, L.M. Nyochembeng and D.A. Mays. 2012. Growth and grain yield of pearl millet (Pennisetum glaucum) genotypes at different levels of nitrogen fertilization in the Southeastern United States. J. Agric. Sci. 4:155-163.

Patel, P.R., B.J. Patel, K.G. Vyas and B.L. Yadav. 2014. Effect of integrated nitrogen management and biofertilizer in Kharif pearl millet (Pennisetum glaucum L.). Adv. Res. J. Crop Improv. 5:122-125.

Patel, V.R., B.M. Patel, J.M Patel and P.M. Patel. 2016. Integrated nitrogen management in summer pearl millet [Pennisetum glaucum (L) R.Br. Emend Stuntz]. Gujarat Agricultural University Research J. 41:61-64.
Pathan, S.H., R.L. Bhilare and S.V. Damame. 2010. Seed yield of forage pearl millet varieties as influenced by nitrogen levels under rainfed condition. Journal of Maharashtra agricultural Universities. 35:306-308

Salama, H.S.A. and M.M.Z. Zeid. 2016. Hay quality evaluation of summer grass and legume forage monocultures and mixtures grown under irrigated conditions. Aust. J. Crop Sci. 10:1543-1550.

SAS Institute Inc. 2012. SAS/STAT® 13.2 User's Guide. Cary, NC: SAS Institute Inc.

Shahin, M.G., R.Th. Abdrabou, W.R. Abdelmoemn and M.H. Hamada. 2013. Response of growth and forage yield of pearl millet (Pennisetum glaucum) to nitrogen fertilization rates and cutting height. Ann. Agric. Sci. 58:153-162.

Simon, T. 2003. Utilization of biological nitrogen fixation for soil evaluation. Plant Soil Environ. 49:359-363.

Singh, D., K. Raghuvanshi, S.K. Pandey and P.J. George. 2016. Effect of biofertilizers on growth and yield of pearl millet (Pennisetum glaucum L.). Res. Environ. Life Sci. 9:385-386.

Thumar, C.M., M.S. Dudhat, N.N. Chaudhari, N.J. Hadiya and N.B. Ahir. 2016. Growth, yield, attributes, yield and economics of summer pearl millet (Pennisetum glaucum L.) as influenced by integrated nutrient management. Int. J. Agric. Sci. 8:3344-3346.

Turan, M., N. Ataoglu and F. Sahin 2005. Evaluation the capacity of phosphate solubilizing bacteria and fungi on different forms of phosphorus in liquid culture. J. Sustain. Agr., 28:99-108.

Vassey, J.K. and T.J. Buss. 2002. Bacillus cereus UW85 inoculation effects on growth, nodulation, and $\mathrm{N}$ accumulation in grain legumes: controlled-environment studies. Can. J. Plant Sci. 82:283-290.

Wani S.P. 1990. Inoculation with associative nitrogen fixing bacteria: Role in cereal grain production improvement. Indian J. Microbiol. 30:363-393.

Winer, B.J. 1971. Statistical principles in experimental design. $2^{\text {nd }}$ Edition. McGraw-Hill Kogakusha, LTD.

Zerbini, E. and D. Thomas. 2003. Opportunities for improvement of nutritive value in sorghum and pearl millet in south Asia through genetic enhancement. Field Crop Res. 84:3-15. 


\section{الملخص العربي}

تأثير استخدام الاسمده المعدنيه والعضويه على كميه المحصول ويعض الصفات المحصوليه للاخن اللؤلؤى

\section{(Pennisetum glaucum L.)}

هند السيد حبيبه، هبه صبرى عطيه سلامه، عبدالعزيز طلعت بندق

تراكم المـاده الجافـه للحشـه الاولى غير معنـوى، بينــا ادت

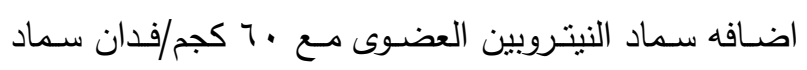

نيتروجين معدنى الى اعلى تراكم للماده الجافه فى الحشنين

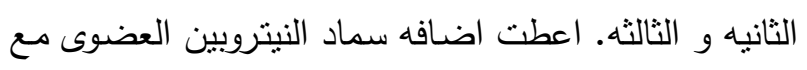

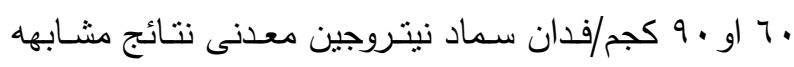

لكميه المحصول مـ الصفات المحصوليه المدروسـه. اثتبت

الاصناف جيزه ا وجيزه r قدرتها الانتاجيه العاليه مع تفوقها الواضـح فى كل الصفات المحصوليه المدروسـه. بينما كانت

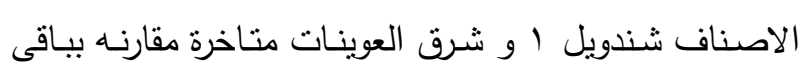
الاصناف المدروسـه. عند دراسـه الحثات التثلاث المتتاليه تم الحصول على اعلى قيم لكل الصفات المدروسه من الحشـه

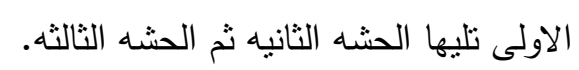
النتائج المتحصـل عليهـا تـرجح اضـافه سـماد النيتروبين العضوى مع معدلات منخفضه من سماد النيتروجين المعدنى

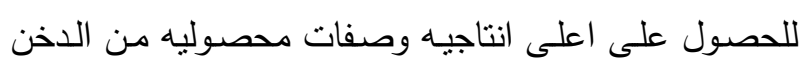
اللؤلوئ.

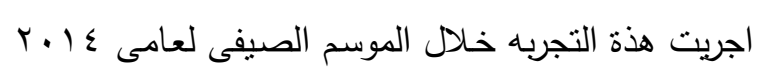

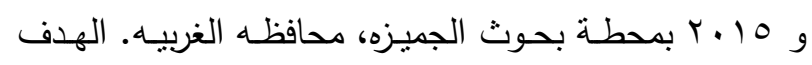

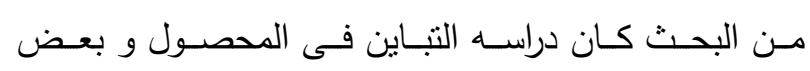
الصفات المحصوليه لثلاث حشات منتاليه من خمس اصناف دخن لؤلؤى منزرعـه في مصر ، تحت تاثير استخدام سماد

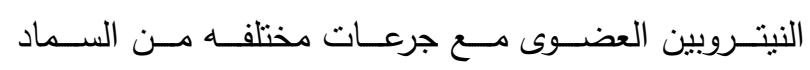

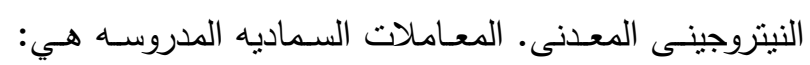

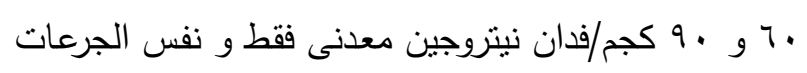

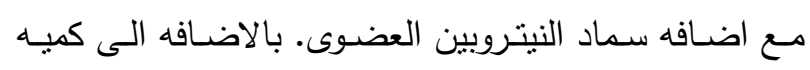

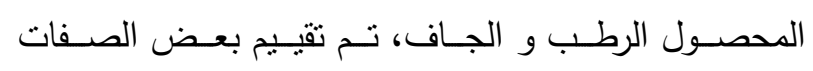

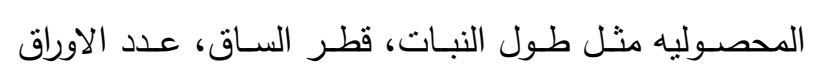
للنبات، المساحه الورقيه للنبات، عدد الافرع و نسبه الاوراق للسيقان. كان هنالك تأثنير واضـح لمعاملات التسميد المختلفه

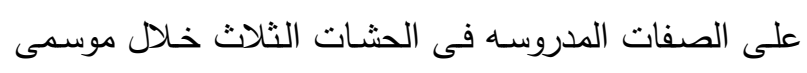

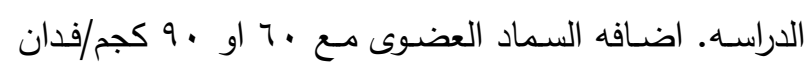
نيتروجين معدنى انتج اعلى كميه محصول رطب و جاف.

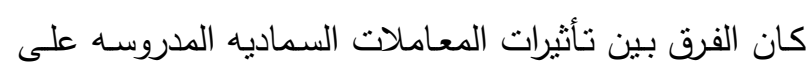

